\title{
Pagden, Anthony. La Ilustración. Y por qué sigue siendo importante para nosotros. Editorial Alianza, 2015. 542pp.
}

\author{
Gabriel Ernesto Tolosa ${ }^{1}$
}

\begin{abstract}
1 nthony Pagden (1945), de origen británico, es profesor de historia y ciencia política en la Universidad de California. Posee una extensa trayectoria, ha pasado por algunas de las más reconocidas universidades británicas y norteamericanas. Tiene publicada una amplia serie de libros cuyo eje principal es la historia de las ideas. El texto que ahora reseñamos es la traducción de su última obra dedicada a la Ilustración, a la que ha dedicado particular atención. Compuesto por una introducción, ocho capítulos y una conclusión. La Ilustración. Y por qué sigue siendo importante para nosotros, se configura como un compendio de historia de las ideas, una síntesis alimentada por una sucesión de argumentos, ninguno completamente original, producto de investigaciones y de una herencia de conocimientos acumulados por varias generaciones de investigadores. Exenta de caracterizarse como una interminable enciclopedia temática sobre el fenómeno intelectual que analiza, esta obra no fue pensada para descifrar en qué pudo consistir la Ilustración, sino con un propósito explícitamente apologético, como puede leerse en su subtítulo.
\end{abstract}

Pagden plantea un gran marco temporal y espacial que podría dividirse, para mayor practicidad, en dos dimensiones: una filosófica y otra histórica. Desde el punto de vista filosófico, las consecuencias de la Ilustración sobre el mundo moderno y su importancia para definir tanto la actualidad como la modernidad -para decirlo a la manera de Michael Foucault cuando examina la respuesta de Kant a la pregunta ¿Qué es la Ilustración? - se sitúa la línea de análisis del libro. Desde el punto de vista histórico, la situación se complejiza más; sin embargo, el carácter abierto de la definición "típica ideal" que se adopta de "Ilustración", permite una perspectiva comprensiva al referirse a sus distintas formas "nacionales", como integrar en el análisis elementos genealógicos para ofrecer un cuadro más acabado del mundo moderno.

Una serie de tópicos relevantes se despliegan en el texto de Pagden cuando expone un esquema de las embestidas que experimenta el proyecto ilustrado. Uno de los más relevantes reside en la crítica

1 Licenciado en Ciencia Política por la Universidad de Ciencias Empresariales y Sociales (UCES), Argentina. Correo Electrónico: gabrielernestotolosa@gmail.com 
simplificada que produjo el Romanticismo, que consistió, ante todo, en una reducción unilateral del hombre a la razón y, por lo tanto, entendida como un intento implacable de imponer a la humanidad entera el peso muerto de lo que sus autores denominaban "El imperio de la razón". Lo que antes pretendía poner en evidencia la confusión intelectual, los engaños perpetrados por la religión y el acrítico apego a las costumbres, ahora se consideraba una forma de engaño. Sin embargo, esto no es lo que más inquieta a Pagden. El peligro lo observa en la crítica de lo imposible de las virtudes universales, al margen de contextos colectivos den los que los individuos se encuentren integrados. Allí, donde resulta más efectiva la capacidad sancionatoria de la comunidad que proviene de lo que Durkheim denominará "conciencia colectiva", y no de una ética singular, el autor considera una forma de retornar al prejuicio que la Ilustración creyó haber derrotado y fragmenta el principio cosmopolita de una ética universal.

Lo que Pagden analiza no se restringe a una Ilustración casi parodiada por sus detractores como un simple movimiento que hacía de la razón su culto, sino un plexo de ideas gnoseológicas y morales cuyo origen se nutrió del escepticismo ante las explicaciones convencionales de la fe y la Escolástica sobre la naturaleza y el hombre. La racionalización cristiana se había debilitado notablemente y, conjuntamente con el nacimiento de nuevas instancias del pensamiento concibieron una atmósfera que patrocinó una de las conquistas humanas más significativas: el carácter indiscutido de los valores que, tradicionalmente, estaba en dominio de la autoridad divina, comenzaba a resquebrajarse y el conocimiento humano abandonaba la unicidad que estaba encarnada por la Providencia. Esta reorientación tuvo como resultado una ciencia del hombre -no solo una antropología, también una historia, una geografía y una lingüística- que se constituyó como una novedad por su contenido y su epistemología aspirando a un estatus metodológico análogo al de las ciencias naturales y fundamentarse a partir de la observación empírica, condición indispensable del pensamiento ilustrado.

La obra permite llevar adelante una serie de planteamientos de los que se pueden inferir algunas objeciones a la manera de tratar el fenómeno por parte del autor. En principio, se puede hacer eje en la pregunta medular, formulada por el teólogo Johann Zöllner, que aparecía en el Monitor de Berlín en 1783: ¿Qué es la Ilustración? Un interrogante que tiende a proponer dos modos de responder, por un lado, en términos del deber ser, o bien, una respuesta producida como construcción de tipo ideal que selecciona determinadas cualidades y deja otras de lado. El autor repetirá varias veces, en relación con la definición de la Ilustración: "Por regla general, se la identifica...", remitiendo a una especie de epistemología de las "convenciones aceptadas". Un artificio adecuado pero que manifiesta la presencia del problema conceptual.

Otra cuestión para considerar, que se desprende del primer interrogante, consiste en el núcleo propiamente histórico del problema. A partir de la selección de determinados rasgos, Pagden intenta definir a la Ilustración, aunque no deja claro la época y las circunstancias que se adoptan para tal selección. Las conexiones que existieron entre los distintos pensadores, su "geografía histórica", no quedan muy claras y, por momentos, dan la impresión de datos aislados. Resulta más provechoso apelar a cuadros más pequeños con historias conectadas y estudios de caso, sin perder una perspectiva general, lo que posibilitará preguntarse más concretamente sobre el impacto del proyecto ilustrado en franjas específicas. Asimismo, esto permitiría analizar el vínculo entre la Ilustración y la difusión de sus ideas fuera de Europa. Reflexionar este fenómeno implica objetar el método y el enfoque de la obra. Las sociedades hispanoamericanas se exponen, como el caso más relevante, a colectividades que apreciaron una "ilustración tardía" frente a Europa y que reveló un aprovechamiento del proyecto ilustrado por momentos más radical que muchas sociedades europeas. Ello se puede observar en el mundo de las 
representaciones y, fundamentalmente, en el mundo de las prácticas, particularmente las que Michel de Certeau denomina "prácticas sin discurso".

Con esquemas panorámicos, Pagden intenta trazar una genealogía de la Ilustración y bosqueja una línea de continuidad, ausente de inconvenientes, entre el proyecto ilustrado, el Renacimiento y la Reforma, lo que puede resultar discutible. Asimismo, su enfoque y método de análisis resultan restringidos porque reduce la Ilustración a una historia de las ideas, cuando fue más una forma de percibir la existencia o una actitud vital, que orientó numerosas iniciativas y realizaciones en una diversidad de campos. No obstante, la obra de Pagden merece ser leída. Se ocupa de manera consistente del fenómeno cultural e intelectual que sentó las bases del mundo moderno. Mediante una secuencia sustentada por una pluralidad de elementos conceptuales, el autor demuestra que la Ilustración logró edificar una idea compleja del ser humano, una idea que no reduce ni la vida social ni la individual a la "razón". Al mismo tiempo, a lo largo del libro, exhibe lo complejo que resulta el proceso por el que las ideas se abren paso en medio de las tradiciones. Tal como lo sostenía Lyotard, los seres humanos son esencialmente criaturas de narraciones y los relatos que se narran entre ellos inventan sus vidas conscientes. Por lo tanto, las conquistas del pensamiento no son estables ni permanentes y siempre pueden volver a estar amenazadas.

\section{Referencias}

De Certeau, Michel. La invención de lo cotidiano. México: Universidad Iberoamericana, 2000. Impreso.

Foucault, Michel. Sobre la Ilustración. Madrid: Teecnos, 2003. Impreso.

Pagden, Anthony. La caída del hombre natural. El indio americano y los orígenes de la etnología comparativa. Madrid: Alianza, 1998. Impreso.

Pagden, Anthony. La Ilustración. Dos ensayos sobre los orígenes de la Modernidad. Barcelona: Península, 2002. Impreso. 